\title{
FACES DO PENTECOSTALISMO BRASILEIRO: A ASSEMBLEIA DE DEUS NO NORTE E NORDESTE
}

\author{
Vanda Pantoja \\ Moab Cesar Carvalho Costa ${ }^{2}$
}

Resumo: Este artigo trata do pentecostalismo brasileiro e suas distintas manifestações. $\mathrm{O}$ trabalho é resultado de recentes pesquisas de campo realizadas pelos autores e se centra em um estudo comparativo do pentecostalismo da Assembleia de Deus nas regiōes Norte e Nordeste do Brasil. O resultado mostra que o pentecostalismo praticado por essa denominação é distinto e varia de acordo com o contexto socioespacial que o produz.

Palavras-chave: Pentecostalismo; Ethos; Teologia da Prosperidade; Usos e costumes.

Abstract: This paper discusses Brazilian pentecostalism and its different manifestations. This work is the result of recent field research conducted by the authors and focuses on a comparative study of pentecostalism in Assembleia de Deus in the North and Northeast of Brazil. The result shows that the pentecostalism practiced by this denomination is different and changes according to the socialspatial context that produced it.

Keywords: Pentecostalism; Ethos; Prosperity Theology; Practices and customs.

O pentecostalismo no Brasil, durante seu primeiro século de existência, passou por várias mudanças. Mudanças significativas no seu conteúdo doutrinário, nas suas práticas litúrgicas e na sua forma de relacionamento com a sociedade. As dimensões continentais do Brasil, o isolamento de determinadas regiōes e sua natureza econômica (rural ou urbana) são responsáveis pela existência simultânea de várias etapas de seu desenvolvimento.

1 Doutora em Antropologia pela Universidade Federal do Pará e professora da Universidade Federal do Maranhão. E-mail: vanpantoja@gmail.com

2 Mestre em Ciências da Religião pela Pontifícia Universidade Católica de Goiás e professor da Universidade Estadual do Maranhão. E-mail: moabcesar@yahoo.com.br

Debates do NER, Porto Alegre, ANo I4, N. 24, P. 245-27I, JUl./DeZ. 2013 
E mesmo dentro de uma única instituição pentecostal, podem-se verificar características diferentes. Caso exemplar é o da Assembleia de Deus no Brasil.

Optamos em fazer um estudo comparativo de duas realidades diferentes dentro de uma mesma instituição, nas regiōes Nordeste e Norte do país. $\mathrm{Na}$ região Nordeste, a Assembleia de Deus localizada na cidade de Imperatriz/MA representa as mudanças que decorrem dos processos de urbanização e modernização tecnológica, por ser uma região de fronteira cultural e economia global, bem como um mercado religioso competitivo e acirrado. Na região Norte, as cidades que fazem parte do arquipélago de Marajó são caracterizadas por uma economia rural, pela manutenção de fortes laços de solidariedade primária e por uma forte tradição religiosa pautada no catolicismo popular e na pajelança.

\section{ASSEMBLEIA DE DEUS EM IMPERATRIZ: ETHOS RELIGIOSO E SEU PROCESSO DE MUTAÇÃO}

A cidade de Imperatriz, localizada no sudoeste maranhense, teve poucas ligações com a capital do Estado, São Luís, no primeiro século de sua existência. Fundada em 1852 pela missão religiosa comandada pelo Frei Manoel Procópio e enviada pelo Estado do Pará, ficou conhecida nos primeiros anos como Povoação de Santa Tereza de Imperatriz. Somente em 1924 foi transformada em cidade, com o nome de Imperatriz. Até os anos de 1950, pela ausência de vias de comunicação, era pequena e isolada dos demais centros. Essa situação de isolamento só vai mudar em 1953, com a construção da estrada que faz a ligação com a cidade de Grajaú e, depois, com construção da rodovia Belém-Brasília, o grande corredor Norte-Sul, que interliga a região de Imperatriz com os grandes centros comerciais do Brasil.

A partir da década de 1950, a cidade de Imperatriz é marcada por uma sucessão de ciclos econômicos, dentre os mais importantes: o ciclo do arroz, o ciclo da madeira e o ciclo do ouro (Serra Pelada). Os ciclos econômicos foram responsáveis pela grande onda de imigrantes que a cidade recebeu. Os fundadores da Assembleia de Deus em Imperatriz, em 1852, eram imigrantes vindos do Estado do Piauí e fugiam da seca em busca de melhores condições de vida no Maranhão.

Debates do NER, Porto Alegre, ANo I4, N. 24, P. 245-27I, JUl./DeZ. 2013 
Os censos do IBGE (1950, 1960, 1970, 1980 e 1991), apresentam a trajetória do crescimento populacional da cidade, e os números mostram que foi na década de 1970 que a cidade de Imperatriz teve uma verdadeira explosão populacional, passando dos 80.827 habitantes, contabilizados pelo censo de 1970, para os 220.095 registrados no censo de 1980. A população praticamente triplicou.

Com um processo de urbanização acelerado, mas sem as condições de infraestrutura adequadas, a cidade cresce desordenadamente e os problemas sociais se avolumam: falta de moradia, hospitais, trabalho e escolas, aumento da criminalidade e da insegurança e inúmeros outros problemas de ordem social. Um verdadeiro estado de marginalização social. Esse estado de instabilidade favoreceu a inserção e crescimento do pentecostalismo.

De acordo com Mariano (2005), a população:

Com o propósito de superar precárias condições de existência, organizar a vida, encontrar sentido, alento e esperança diante de situação tão desesperadora, os estratos mais simples, mais sofridos, mais escuros e menos escolarizados da população, isto é, os mais marginalizados - distantes do catolicismo oficial, alheios aos sindicatos, desconfiados dos partidos políticos e abandonados à própria sorte pelos poderes públicos -, têm optado voluntária e preferencialmente pelas igrejas pentecostais (Mariano, 2005, p. 12).

Por décadas, Imperatriz era vista como uma área de fronteira, um lugar de ninguém e uma terra de estrangeiros, ao mesmo tempo que representava um lugar de luta e esperança por uma vida melhor. É na Igreja Assembleia de Deus que parte considerável da população vai encontrar apoio e sentido para prosseguir na busca por melhores condiçôes de vida e pela expectativa de uma vida eterna no paraíso de Deus.

Os censos do IBGE de 1950 a 2000 revelam não apenas o crescimento acelerado da cidade de Imperatriz, mas trazem também informações significativas sobre o seu campo religioso. É somente a partir do censo de 1980 que o IBGE introduz uma classificação do protestantismo como tradicional (histórico) e pentecostal.

Debates do NER, Porto Alegre, ANo I4, N. 24, P. 245-27I, JUl./DeZ. 2013 
Deve-se observar que numa cidade como Imperatriz, onde o fluxo migratório é constante, a pluralidade religiosa tende a ser mais expressiva. Em 1980, sua população era composta por $11 \%$ de maranhenses, $22 \%$ de pessoas de outros Estados do Nordeste e 67\% de pessoas de outras regiōes do país.

No censo de 1991, aparecem de forma destacada aqueles que se declaram sem religião: 8.797 pessoas $(3,18 \%)$. Os que não declararam ficaram em $465(0,16 \%)$. Seguem os espíritas, com 581 pessoas $(0,21 \%)$; candomblé e umbanda, com 299 (0,11\%); religiões orientais, 92 seguidores; judeus, 40; e outros com 25.

O censo de 2000 traz outra novidade em relação ao de 1991: a classificação do campo religioso é mais detalhada e fala-se não apenas de católicos, protestantes e pentecostais, mas de denominações de origem evangélica de missóes e de origem pentecostal, nominando cada uma delas. Ou seja, trazem dados específicos sobre os batistas, assembleianos, testemunhas de Jeová, quadrangulares, adventistas, luteranos, presbiterianos, Congregacionistas Cristãos e universais do reino de Deus, assim como sobre outras religióes de origem pentecostal, espírita, afro e oriental e também sobre aqueles que se declaram sem religião, cujo número praticamente dobrou na última década, de $8.797(3,18 \%)$ para $15.169(6,58 \%)$.

Ainda classificada como igreja de origem pentecostal, a Igreja Universal do Reino de Deus - IURD, no censo de 2000 já aparece com 2.025 membros (0,88\%), e a AD aparece com 29.978 (13\%). Esse crescimento da IURD e o surgimento de dezenas de instituiçôes neopentecostais na cidade de Imperatriz têm provocado mudanças significativas em seu campo religioso.

Nesse espaço, podemos observar mais claramente as transformações pela quais passa o pentecostalismo representado pela Assembleia de Deus, e essas transformações ocorrem, fundamentalmente, no ethos que a caracterizava como clássica. O que se observou foi um processo de neopentecostalização de suas práticas e crenças, ou seja, a adoção de um ethos de afirmação de mundo em substituição ao ethos de rejeição de mundo.

Essa mudança de ethos é uma resposta religiosa às novas exigências do sistema capitalista atual (sociedade de consumo) e às pressões sofridas no

Debates do NER, Porto Alegre, ANo I4, N. 24, P. 245-27I, JUl./DEZ. 2013 
campo religioso em função da chegada de novas instituições, que passam a fazer concorrência e dividem com ela o prestígio e o poder simbólico local, constituindo uma situação de mercado, conforme Guerra (2003).

Em pesquisa recente apontamos - em virtude do crescimento meteórico das igrejas neopentecostais - o neopentecostalismo como um modelo que tem sido seguido (adaptado) pelas principais igrejas que representam o pentecostalismo, tanto o clássico como o de cura divina. Neste artigo nossas considerações se focarão nas modificaçôes e adaptaçôes que estão ocorrendo nas Assembleias de Deus na cidade de Imperatriz/MA.

Também foi possível destacar que a adoção das crenças e práticas do neopentecostalismo significam uma mudança de ethos, ou seja, a substituição de um ethos marcado pela ascese sectária por um de afirmação de mundo. Denominamos essas mudanças de neopentecostalização.

Vamos iniciar definindo o que é ethos, para em seguida tratar do processo de neopentecostalização da Assembleia de Deus.

A etimologia da palavra ethos tem origem grega, designando costume ou "moradia", "o lugar onde se vive", o caráter, o modo de ser no mundo, a origem dos valores e as normas que estruturam uma civilização, um povo, um grupo social ou simplesmente um indivíduo. De uma maneira geral, ethos indica os traços característicos de um grupo, do ponto de vista social e cultural, e o que o diferencia de outros. Assim entendido, o ethos seria um valor de identidade social.

Agostini (1992) resume em poucas palavras o significado desse termo grego:

O ethos é o ponto de partida para a compreensão do que funda o "humanum", ou seja, ele é como que o alicerce que sustenta o humano como fonte borbulhante e dinâmica, não estática, o ethos está na origem das normas e da própria diversidade das culturas e religiōes (Agostini, 1992, p. 21).

No seu cotidiano, o ser humano sente a necessidade de organizar a sua vida a partir de suas relações fundamentais consigo mesmo, com o outro, com o mundo e com a transcendência (Deus). A cada dia se apresenta aos

Debates do NER, Porto Alegre, ANo I4, N. 24, P. 245-27I, JUl./DeZ. 2013 
homens novos e diferentes desafios. Sabe-se que é próprio do ser humano, uma vez desprovido do instinto, dar a resposta adequada conforme o lugar, o tempo, os costumes etc.

Cada grupo, aos poucos, cria um modo próprio e habitual de compreender o mundo. $\mathrm{O}$ ethos aqui é entendido como o lugar onde os costumes, a moral e os valores são não apenas elaborados, mas também modificados, de acordo com as inúmeras negociações que o ser humano faz com as diversas circunstâncias que lhe sobrevêm. O ethos é mutante. No entanto, sua mutação se faz de forma lenta, principalmente nas culturas mais tradicionais e nos meios rurais, onde a tradição domina muito mais o indivíduo do que o meio urbano moderno e pós-moderno. Do ethos também emana todo o mundo simbólico e mítico, ou seja, os valores que sustentam a vida em suas multifaces.

De acordo com essa percepção, podemos afirmar que o pentecostalismo clássico, que aqui será representado pela Assembleia de Deus, possui um ethos próprio, uma forma de ver, compreender e reagir no mundo. $\mathrm{O}$ ethos religioso, portanto, é manifesto nas crenças e práticas, nos ritos e na percepção dos símbolos, bem como nos significados a eles estabelecidos por uma determinada tradição religiosa ou segmento dela. $\mathrm{O}$ ethos possui função nomizadora!

Geertz (2008) retrata de que forma o ethos religioso atua sobre o grupo ou indivíduo, produzindo um nomos que satisfaz as suas necessidades de sentido para a vida e para a transcendência:

$\mathrm{Na}$ crença e na prática religiosa, o ethos de um grupo torna-se intelectualmente razoável porque demonstra representar um tipo de vida idealmente adaptado ao estado de coisas atual que a visão de mundo descreve, enquanto essa visão de mundo torna-se emocionalmente convincente por ser apresentada como uma imagem de um estado de coisas verdadeiro, especialmente bem-arrumado para acomodar tal tipo de vida (Geertz, 2008, p. 67).

Nesse aspecto, a religião cria um ethos próprio, um cosmo, situando o indivíduo ou o grupo numa realidade convincente, onde os padrões éticos e morais são elaborados, legitimados e impregnados de tal forma que se torna a única realidade capaz de acomodar todas as suas inquietações, sejam elas imanentes ou transcendentes.

Debates do NER, Porto Alegre, ANo I4, N. 24, P. 245-27I, JUl./DEZ. 2013 
A religião é parte constituinte da cultura. A força que ela exerce sobre os indivíduos é tal que os símbolos que a representam e dão vida ao sagrado, bem como os objetos e os ritos que descrevem sua origem e trajetória, impõem e exigem não só uma obrigação, mas uma aceitação intelectual e um compromisso emocional, de maneira que uma ação ou comportamento contrário produz anomia e caos.

Mais uma vez, remontando a Geertz (2008, p. 94), constata-se que:

A religião nunca é apenas metafisica. Em todos os povos as formas, os veículos e os objetos de culto são rodeados por uma aura de profunda seriedade moral. Em todo lugar, o sagrado contém em si mesmo um sentido de obrigação intrínseca: ele não apenas encoraja a devoção como a exige; não apenas induz a aceitação intelectual como reforça o compromisso emocional (Geertz, 2008, p. 94).

Essa seriedade moral, fruto das convenções sociais e infundida nas consciências como uma ordem natural e intrínseca da realidade, modifica-se à medida que a sociedade renegocia seus valores com as novas circunstâncias produzidas pelo meio. Nesse caso, o ethos se acomoda e se modifica, produzindo lenitivo e gerando nomia, ressignificando seus valores e legitimando a nova ordem.

Quanto mais moderna e urbana é a sociedade, menos profundas são suas raízes culturais e mais facilmente podem ser removidas e substituídas. Por conseguinte, o ethos religioso também produz suas novas leituras e assimila novos modelos éticos e morais, impondo-se como obrigação intrínseca capaz de acomodar sentimentos e emoções. Dessa forma, podemos então afirmar que o ethos é a configuração, sempre em mutação, psicocultural de um indivíduo ou de uma sociedade.

Nesse caso, o conceito de cultura desenvolvido por Geertz (2008) fortalece nossa posição de que o ethos, como parte essencial e estruturante de uma cultura específica, modifica-se sempre que as circunstâncias exigem um novo padrão de valores. Reforçando esse posicionamento, também nos mostra como a cultura é composta pelo ethos e pela visão de mundo, que enquanto valores, construçôes e práticas se sobrepõem sucessivamente na organização da vida social.

Debates do NER, Porto Alegre, ANo I4, N. 24, P. 245-27I, JUl./DeZ. 2013 
Vivemos muito mais concretamente sob a nossa visão de mundo do que de nosso ethos. A religião constitui e expressa o ethos e a visão de mundo de uma sociedade. No entanto, a experiência religiosa está muito mais marcada pelo ethos do que pela visão de mundo. Ao compreendermos os mecanismos sociais que movem a religião, entendemos como a sociedade é e como ela age sobre os indivíduos.

Nessa concepção é que elaboramos a hipótese de uma mudança de ethos no pentecostalismo clássico brasileiro, especificamente na Assembleia de Deus. Ou seja, a mudança do mundo simbólico e dos valores éticos e morais que sustentam e norteiam a identidade dos membros da Assembleia de Deus. $\mathrm{Na}$ sua origem, a elaboração de seu conteúdo moral e ético sofre influência forte do ethos da sociedade sueca, trazido pelos missionários Daniel Berg e Gunnar Vingren e caracterizado pela ascese sectária das primeiras décadas do século vinte, imbricando-se com o ethos autoritário e patriarcal presente na sociedade nordestina. Dessa junção surge, conforme Freston (1993), um modo de vida peculiar, característico dos membros da $\mathrm{AD}$, que eram facilmente reconhecidos pela sociedade por seus aspectos estéticos e morais.

Até meados de 1970, era muito comum ouvir alguém falar "aquele ali é crente, um evangélico da Assembleia de Deus. Dá pra saber só olhando o jeito dele se vestir e se comportar". Expressões como estas serviam claramente para demonstrar que os membros da $\mathrm{AD}$, de certa forma, representavam um estereótipo do fiel evangélico no Brasil, caracterizado pelo radicalismo, inflexibilidade doutrinária, negação da alteridade e extremo ascetismo em relação à vida secular e à cultura social vigente. Ou seja, ainda podia ser percebido o paradigma da ascese intramundana observada por Weber (2001; 2009) e originada na Reforma Protestante, mais especificamente na doutrina da predestinação de Calvino.

Veremos a seguir os traços que caracterizam o ethos neopentecostal e quais deles estão sendo absolvidos pela Assembleia de Deus na cidade de Imperatriz/MA.

Debates do NER, Porto Alegre, ANo I4, N. 24, P. 245-27I, JUl./DEZ. 2013 


\section{O ETHOS RELIGIOSO DE AFIRMAÇÃO DE MUNDO: O NEOPENTECOSTAL}

O neopentecostalismo cujo tipo ideal é representado pela Igreja Universal do Reino de Deus - IURD - desenvolveu uma nova forma de relacionamento com a sociedade, reduziu as tensões existentes e rompeu radicalmente com a ascese sectária e intramundana através da adoção da Teologia da Prosperidade, criando assim um novo paradigma religioso no campo pentecostal brasileiro.

De fato, o primeiro princípio doutrinário em que se fundamenta a prática religiosa das igrejas neopentecostais, independente de ser diferenciada sua liturgia, é a "teologia da prosperidade", segundo a qual todos os fiéis, ao se converterem, "nascidos de novo" em Cristo, são reconhecidos como "filhos de Deus" (Montes, 1998, p. 120).

O neopentecostalismo provocou mudanças em todo o campo religioso brasileiro, voltando-se para a massificação da fé e com um ethos de afirmação de mundo, transmitido principalmente através da Teologia da Prosperidade. De modo geral, podemos relacionar alguns elementos que compõem o ethos neopentecostal. São eles:

a. O mal deve ser combatido, e ele se expressa através de demônios ou encostos, que são causadores de doenças, pobreza, desuniões e violência. Tendo todas essas coisas origem sobrenatural, sua solução também é sobrenatural, e se dá através de uma guerra santa contra Satanás e seus demônios;

b. Não existe uma forma rígida de controle da conduta do fiel. Ele deve contribuir sempre para a promoção da guerra contra o mal. Geralmente essa contribuição é financeira;

c. Os valores que mais devem ser buscados são: a saúde, a paz de espírito (pelo exorcismo) e a riqueza material, sinal de que Deus o está

Debates do NER, Porto Alegre, ANo I4, N. 24, P. 245-27I, JUl./DeZ. 2013 
abençoando ${ }^{3}$. Essa riqueza é diretamente proporcional às ofertas ou "sacrifícios" financeiros feitos à igreja;

d. O liberalismo sexual é combatido como uma influência do demônio na vida daqueles que praticam a infidelidade conjugal;

e. A família é um bem precioso e deve ser preservada e mantida de acordo com a determinação de Deus: monogâmica, heterossexual e com fidelidade conjugal para os dois cônjuges. Os conflitos familiares são provocados pelos demônios.

Em linhas gerais, quatro são os elementos que configuram o neopentecostalismo e, em consequência deles, vários outros aspectos se desenvolvem na formação do novo paradigma pentecostal brasileiro. Embora o neopentecostalismo não rompa, e nem possa romper, com o pentecostalismo (pois se o fizer fica sem referências legitimadoras), ressignifica seus valores, modifica seus padrōes e estabelece novos métodos de proselitismo e de relação com a sociedade.

É consenso entre os estudiosos já citados que os elementos gerais que caracterizam o neopentecostalismo são: Guerra Santa, Teologia da Prosperidade, Liberalização dos aspectos externos da moral e santidade pentecostal (usos e costumes que caracterizam a ascese sectária do pentecostalismo clássico) e a empresarização do sagrado ou a adoção da lógica da moderna administração capitalista no empreendimento religioso, sobretudo no marketing e na ampla utilização dos meios de comunicação, como o rádio e a TV.

Para uma compreensão mais clara sobre o porquê do abrandamento do ethos ascético do pentecostalismo clássico por parte das igrejas neopente-

3 De acordo com Montes (1998), este sinal de que Deus o está abençoando não pode ser associado ao sinal da Eleição, preconizado pela doutrina calvinista da predestinação (analisado por Weber na obra Ética protestante e o espírito do capitalismo), uma vez que a teoria da predestinação está associada à ética do trabalho, cujos bons resultados eram vistos como prova da eleição de Deus para uma salvação na vida eterna. No neopentecostalismo, a busca é pelo aqui e o agora.

Debates do NER, Porto Alegre, ANo I4, N. 24, P. 245-27I, JUl./DEZ. 2013 
costais, numa aproximação ou conformação com a sociedade vigente e seu sistema econômico, faz-se necessário conectá-lo com a concepção weberiana de cotidianização do carisma, entendendo, assim, as razões para a adoção de um ethos de afirmação de mundo, compatível com o sistema capitalista atual, globalizado.

Sobre a cotidianização do carisma, Weber (2009) faz a seguinte afirmação:

Condição prévia da rotinização do carisma é a eliminação de sua atitude alheia à economia, sua adaptação a formas fiscais (financeiras) da provisão das necessidades, e com isso, a condições econômicas capazes de render impostos e tributos (Weber, 2009, p. 165).

À medida que a sociedade absorve os valores do sistema capitalista atual, marcado, acima de tudo, pelo estímulo ao consumo, os valores ascéticos impostos pelos regimentos e doutrinas das igrejas vão sendo suavizados, abrandados e, por fim, abandonados, para que os mesmos não sejam motivo para a perda do fiel. Se o que a sociedade busca e almeja é o aumento considerável de sua capacidade de consumo, a igreja estimula esse consumo e aponta, dentro de suas práticas, os mecanismos de sua conquista.

O neopentecostalismo possui características bem distintas do pentecostalismo clássico e seus elementos são claramente distinguidos nas instituições que representam o modelo neopentecostal. Ampliando a discussão sobre os elementos que caracterizam o neopentecostalismo, Mariano (2005) relaciona, além dos quatro elementos, outros aspectos fundamentais. São eles:

- Desenvolvimento de um ethos de afirmação de mundo;

- Falta de homogeneidade teológica (embora também não exista no pentecostalismo clássico e no da segunda onda);

- Rompimento com a busca da salvação pelo ascetismo de rejeição de mundo; 
- Distanciamento da escatologia premilenarista, baseada na eterna e resignada espera pelo retorno de Cristo, priorizando o aqui e o agora.

Apresenta, ainda, outros aspectos de natureza não teológica, mas de logística e marketing que diferenciam o neopentecostalismo do pentecostalismo:

- A estética dos cultos;

- Deslocamento do espaço sagrado;

- Caráter de espetáculo;

- Terceirização de serviços (agenciamento de instâncias não religiosas para a funcionalização da liturgia);

- Caráter empresarial do serviço religioso;

- Modernização da linguagem: áudio e visual da liturgia;

- Ampla utilização dos meios de comunicação em massa (mídia) nas ações proselitistas.

A adoção de um novo ethos religioso passa pela releitura de mundo e das circunstâncias que cercam o sujeito ou o grupo social nele envolvido. A religião estrutura e é estruturada pela sociedade, sofre sua influência e se molda ou se acomoda no todo ou em parte aos valores que nela se impóe. Essa acomodação só ocorre quando passa a existir novos elementos, em oposição aos anteriores, que justifiquem e legitimem o novo estado de coisas, que ao ressignificar os valores anteriormente adotados e consagrados como realidade, sejam capazes de responder todas as inquietações do grupo, não produzam anomia e nem desconstruam os alicerces primordiais e fundamentais da fé adotada e praticada, mas reforce o sentimento de pertença, de identidade social 
e de segurança da escolha religiosa e proporcione o mais agradável bem-estar possível aos seus adeptos diante da nova ordem ética, moral e estética adotada.

É exatamente essa sensação que a Teologia da Prosperidade produz nos adeptos do neopentecostalismo, e é por isso que atrai e influencia atores sociais de outros segmentos religiosos da tradição cristã.

A seguir veremos como a Teologia da Prosperidade se constitui veículo e força legitimadora do ethos de afirmação de mundo e do consequente processo de neopentecostalização da Assembleia de Deus em Imperatriz/MA.

\section{TEOLOGIA DA PROSPERIDADE COMO VEÍCULO DE NEOPENTECOSTALIZAÇÃO}

A "teologia da prosperidade" serve perfeitamente aos interesses de um pentecostalismo de acomodação a um novo estágio sócio-econômico da sociedade Ocidental. Isto porque, é uma teologia que não se rege pelos ditames da fuga e sim, por uma imersão na sociedade em sua dimensão econômica (Campos, 1999, p. 375).

A Teologia da Prosperidade ou Confissão Positiva teve sua origem na década de 1940, nos Estados Unidos, sendo reconhecida como doutrina na década de 1970, quando se difundiu pelo meio evangélico. Possuía um forte cunho de autoajuda e valorização do indivíduo, agregando crenças sobre cura, prosperidade e poder da fé, por meio da confissão positiva e em Nome de Jesus, para recebimento das bênçãos materiais, de saúde para o corpo e de libertação das opressóes malignas (Romeiro, 2005, p. 87-116).

Por meio da Confissão Positiva, o cristão compreende que tem direito a tudo de bom e de melhor que a vida pode oferecer: saúde perfeita, riqueza material e poder para subjugar Satanás e seus demônios ${ }^{4}$ - responsáveis diretos pela infelicidade do homem -, uma vida plena de felicidade e bem-aventuranças.

4 A ideia de que Deus retribui a fé com riqueza material e a ideia de que demônios interferem em nossa vida, atrapalhando a prosperidade material, são pilares básicos da Teologia da Prosperidade.

Debates do NER, Porto Alegre, ANo I4, N. 24, P. 245-27I, JUl./DeZ. 2013 
Em contrapartida, dele era esperado que não duvidasse do recebimento da bênção, pois isso acarretaria em sua perda, com o consequente triunfo do Diabo. A relação entre o fiel e Deus ocorre pela reciprocidade, pela compreensão de que é dando que se recebe e pelo sacrifício financeiro, prova de fé inconteste em Deus e em sua provisão. As bênçãos são proporcionais às ofertas.

A difusão da Teologia da Prosperidade encontrou grande aceitação no meio pentecostal brasileiro. Atraiu milhões de pessoas para as igrejas em busca de um enriquecimento fácil e de prosperidade, sem ter, necessariamente, uma relação direta com o trabalho, uma vez que nas campanhas os pregadores mais entusiastas prometem aos que fazem ofertas financeiras soluções antes nunca imaginadas: retirar miraculosamente o nome dos mecanismos de controle de crédito como o Serasa e o SPC, cobrir o débito do cheque especial e do cartão de crédito, facilitar os processos de aposentadoria etc.

Outro pressuposto da pregação da confissão positiva é o arranjo teológico encontrado por seus propaladores para justificar e legitimar a riqueza, o sucesso e a saúde física como sinais inquestionáveis da presença de Deus na vida das pessoas. Se antes era "[...] mais fácil entrar um camelo pelo fundo de uma agulha do que entrar um rico no reino de Deus" (Lucas 18: 25), a inversão de valores é radical: pobreza passa a significar falta de fé, e "[...] sem fé é impossível agradar-lhe; porque é necessário que aquele que se aproxima de Deus creia que ele existe, e que é galardoador dos que o buscam" (Hebreus 11: 6) e, sem agradar a Deus, não se pode pensar em salvação.

Despojados da riqueza e da saúde, os pobres e marginalizados projetavam suas bem-aventuranças nos céus e na morada eterna prometida por Deus aos seus filhos. Com a Teologia da Prosperidade elevada à condição de "vontade de Deus" para os homens, o céu ficou mais distante, e para conquistá-lo é preciso ser rico e próspero. A oferta religiosa neopentecostal, por meio da Teologia da Prosperidade, coloca a riqueza em primeiro plano e a constitui conditio sine qua non para atingir a salvação.

Para Mariano, no neopentecostalismo:

Invertem a postura pentecostal tradicional de rejeição à busca da riqueza, ao livre gozo do dinheiro, de status social e dos prazeres desse mundo. Em seu

Debates do NER, Porto Alegre, ANo I4, N. 24, P. 245-27I, JUl./DEZ. 2013 
lugar pregam a teologia da prosperidade, doutrina que, grosso modo, defende que o crente está destinado a ser próspero, saudável e feliz neste mundo. E, com isso, em vez de rejeitar o mundo, os neopentecostais passaram a afirmá-lo (Mariano, 2005, p. 42).

Para o indivíduo, a busca pela prosperidade não se constitui num caminho para chegar aos céus. Antes, significa encontrar condições para atender as exigências da sociedade de consumo (viver o aqui e o agora, como se a vida fosse um eterno presente). Para as instituiçóes religiosas, a adoção da Teologia da Prosperidade significa a utilização de métodos e estratégias de acomodação aos processos sociais e às pressóes e conflitos existentes no mercado religioso.

Nesse sentido, a Teologia da Prosperidade é o veículo utilizado pelas instituiçóes religiosas para responder às pressóes do sistema capitalista atual (sociedade de consumo) e da concorrência e conflitividade do mercado religioso. Em consequência, a Teologia da Prosperidade se conecta com o capitalismo e a modernidade tardia através da noção de concorrência, de sucesso do indivíduo e de reconhecimento.

Campos (1999) compartilha do mesmo entendimento e vai além, ao afirmar que a acomodação social adotada pelas igrejas se constitui numa imersão da religião na dinâmica econômica de mercado, de sorte que ela não só utiliza os mecanismos de mercado para "vender" seus produtos de bens de salvação, como também se torna um produto de mercado.

As mudanças ocorridas no campo religioso pentecostal, motivadas pela entrada das igrejas neopentecostais, acirraram a concorrência no mercado dos bens simbólicos, forçando as igrejas do pentecostalismo clássico a promoverem mudanças em sua forma de se relacionar com a sociedade e com seus membros. Esse processo de acomodação refletiu diretamente no conjunto de suas crenças e ritos.

Em Imperatriz/MA, a Assembleia de Deus assimilou elementos do neopentecostalismo, reordenou sua relação com a sociedade capitalista, adotou - ainda que muitos pastores neguem - a Teologia da Prosperidade e abrandou os estereótipos de santidade pentecostal (os usos e costumes). Entre os vários elementos adotados, podemos citar:

Debates do NER, Porto Alegre, ANo I4, N. 24, P. 245-27I, JUl./DeZ. 2013 
- Utilização ampla do rádio e da TV na evangelização, com suporte de marketing em suas ações;

- Promoção sistemática e regular de campanhas de prosperidade;

- Ritos muito próximos, em algumas campanhas e em pregadores mais ousados, dos realizados na IURD, com utilização de objetos (água ungida, pedras, óleo, rosas, miniaturas de objetos do interior do Templo de Salomão, corredor dos milagres, unção de objetos pessoais, fotografias etc.);

- Realização de show gospel com objetivo de arrecadar recursos;

- Participação ativa na política partidária como forma manter um relacionamento mais estreito com os poderes públicos;

- Departamentalização institucional e estabelecimento de metas financeiras por congregaçóes e promoções internas baseadas em seu cumprimento.

A presença de todos os elementos acima citados, nas práticas e crenças da Assembleia de Deus em Imperatriz demonstra, de forma inquestionável, que a mesma passa por um processo de mudança de ethos. De um ethos sectário e ascético para um de afirmação de mundo. Essa mudança é um sinal claro de sua neopentecostalização.

Deve-se esclarecer que o processo de neopentecostalização que está ocorrendo na Assembleia de Deus em Imperatriz não é isolado dentro das AD's. Ocorre em todo o Brasil e, em alguns lugares, de forma muito mais acentuada, como é o caso das AD's ligadas ao ministério Madureira, que recentemente assumiu de forma oficial sua nova condição (ISTOÉ, 2011), e das AD's localizadas nos centros urbanos mais desenvolvidos.

Não obstante, como veremos a seguir, existem algumas regiōes no Brasil cujo isolacionismo momentâneo e suas características rurais têm preservado os traços originais das Assembleias de Deus no Brasil.

Debates do NER, Porto Alegre, ANo I4, N. 24, P. 245-27I, JUl./DEZ. 2013 


\section{ASSEMBLEIA DE DEUS NO MARAJÓ: OS USOS E COSTUMES}

As 16 cidades da Mesorregião Marajó, no estado do Pará5, são de ocupação bastante antiga, remetendo aos séculos XVII e XVIII, e têm uma forte tradição religiosa pautada no catolicismo popular, na pajelança e em religiões de matriz africana. São cidades relativamente pequenas, variando entre 6 e 100 mil habitantes, economicamente apresentam Índices de Desenvolvimento Humano - IDH - bastante baixos, estão localizadas longe dos centros urbanos e cultivam um modelo de vida comunitário em sua maioria. Religiosamente, possuem forte influencia do catolicismo popular e têm nas festas de santos e santos católicos seus momentos festivos mais marcantes. A introdução do protestantismo pentecostal na região é bastante antiga ${ }^{6}$, mas sua difusão com maior força se deu nas últimas duas décadas do século XX, como se observa no quadro abaixo.

\footnotetext{
5 A Mesorregião Marajó é uma das cinco mesorregiōes em que se divide o estado do Pará, e abrange 16 municípios: Soure, Salvaterra, Cachoeira do Arari, Santa Cruz do Arari, Ponta de Pedras, Anajás, Curralinho, Breves, Portel, Gurupá, Afuá, Chaves, Bagre, São Sebastião da Boa Vista, Muaná e Melgaço. Na Mesorregião está a Ilha do Marajó que, dos municípios citados, abrange 12 .

6 O Marajó foi, depois da capital Belém, para onde se dirigiu Gunnar Vingren, fundador da Assembleia de Deus em Belém, em 1911, quando decidiu que estava na hora de expandir o pentecostalismo na região. Suas memórias, publicadas por seu filho Ivar Vingren (2000) relatam que antes mesmo da consolidação na capital paraense já se faziam incursões pelos rios da região, pregando e realizando cultos nas casas dos ribeirinhos.
}

Debates do NER, Porto Alegre, ANo I4, N. 24, P. 245-27I, JUl./DeZ. 2013 
Tabela 1 - Evangélicos por municípios da Mesorregiāo Marajó nos censos de 1991 e 2000

\begin{tabular}{|c|c|c|}
\hline Municípios & População 1991/2000 & Evangélicos 1991/2000 (\%) \\
\hline Afuá & $20.008 / 29.505$ & $15,3 / 13,7$ \\
\hline Anajás & $14.428 / 18.322$ & $24,6 / 29,4$ \\
\hline Bagre & $13.844 / 13.708$ & $24,6 / 34,15$ \\
\hline Breves & $72.140 / 80.158$ & $13 / 19,9$ \\
\hline Cachoeira do Arari & $13.246 / 15.783$ & $12 / 18,1$ \\
\hline Chaves & $17.400 / 17.350$ & $9,8 / 25,5$ \\
\hline Curralinho & $15.204 / 20.016$ & $13,2 / 18,07$ \\
\hline Gurupá & $18.969 / 23.098$ & $3,5 / 6,95$ \\
\hline Melgaço & $14.538 / 21.064$ & $13 / 17,2$ \\
\hline Muaná & $22.367 / 25.467$ & $13 / 20,7$ \\
\hline Ponta de Pedras & $16.500 / 18.694$ & $10,8 / 26,9$ \\
\hline Portel & $29.452 / 38.043$ & $5,2 / 14,2$ \\
\hline Salvaterra & $11.889 / 15.118$ & $7 / 14,3$ \\
\hline Santa C.do Arari & $4.774 / 5.255$ & $14,2 / 24,85$ \\
\hline São S. da B.Vista & $14.926 / 17.664$ & $5 / 9$ \\
\hline Soure & $17.481 / 19.958$ & \\
\hline
\end{tabular}

Fonte: IBGE. Organizado pela autora.

Pode-se dizer que o pentecostalismo passa por um duplo processo de adaptação na região: tanto ele se adapta à região como a região se adapta a esse modelo de crença que, para muitos, é demasiado estranho ao lugar. Uma dessas adaptações se percebe em relação às ressignificações pelas quais passam as práticas católicas, tendo em vista a forte presença pentecostal na região ${ }^{7}$.

No processo de adaptação, o pentecostalismo necessita se ajustar a uma certa cultura amazônica, que tem no catolicismo popular e nas crenças que envolvem entidades do universo da pajelança fortes componentes. $\mathrm{O}$ meio ecológico é outra variável importante nesse processo, já que grande parte das crenças locais têm no rio e na floresta suas fontes de inspiração.

Além dessa adaptação a uma cultura construída com forte referencia aos aspectos ecológicos da região, os pentecostais necessitam impor-se frente a

7 Conferir Pantoja, 2011.

Debates do NER, Porto Alegre, ANo I4, N. 24, P. 245-27I, JUl./DEZ. 2013 
uma Igreja Católica que, apesar de não muito presente fisicamente, deixou forte marca de sua catequese na região.

Segundo Pierre Sanchis (1997), no Brasil a diversidade religiosa é, ao mesmo tempo, institucional e subjetiva, e não constitui uma novidade, apesar de sua intensidade e modalidade se apresentar bastante criadora em tempos mais recentes. Em sua avaliação, a emergência desse fenômeno aos olhos dos cientistas somente nas últimas décadas está mais relacionada à troca de instrumentos de análise e menos ao fato do tema da diversidade religiosa ser uma novidade. Como bem afirmou Sanchis, o universo religioso brasileiro é marcado por múltiplos pertencimentos religiosos. Nessa parte da Amazônia não é diferente. Tanto seu processo histórico, marcado pelo encontro de diferentes povos, como suas características naturais da região, marcada pelo domínio de rios e florestas e local de morada de várias entidades do universo da pajelança - prática local influenciada por diversas formas religiosas cristãs e não cristãs - o repertório religioso dessa parte da Amazônia se (re)constitui por diferentes traços que não param de se multiplicar. Da pajelança indígena, do catolicismo europeu, de religiōes de inspiração afro, do catolicismo popular, do espiritismo kardecista, de várias vertentes do protestantismo e de muitas outras formas de crer que não cessam de aparecer.

Até na difusão do pentecostalismo na região, ser católico era a condição do lugar, e mesmo as outras práticas religiosas, a exemplo da pajelança, estavam sob o manto do catolicismo.

Nas pesquisas sobre catolicismo popular realizadas por Maués (1995) na região Nordeste Paraense, na década de 1980, ele verificou que ser pajé não impede ninguém de ser católico. É como se ser católico fizesse parte da condição de ser pajé, não havendo nenhuma linha de ruptura no imaginário popular amazônico entre a pajelança e o catolicismo. Maués constatou que os praticantes da pajelança se identificavam e eram identificados como católicos; os praticantes da umbanda e os adeptos do espiritismo kardecista assumiam uma identidade umbandista ou espírita, mas no caso dos pajés, sequer existia uma nomenclatura nativa que designasse tal identidade, pois

Debates do NER, Porto Alegre, ANo I4, N. 24, P. 245-27I, JUl./DeZ. 2013 
os mesmos procuravam sempre mostrar-se como "bons católicos" ${ }^{8}$. Isso é possível, segundo Maués, devido ao caráter sincrético do catolicismo, que possibilita que o mesmo "saiba conviver com as diferenças" assimilando-as, até certo ponto, mas, ainda assim, preservando um "núcleo essencial de fé cristã" e, consequentemente, uma "identidade católica". O mesmo processo não é possível, segundo Maués (1995, p. 484), no caso do protestantismo que, por tender ao sacerdócio universal, se fragmenta em numerosas igrejas e "seitas". Disso se apreende que, se entre os católicos e os adeptos da pajelança foi construída uma linha de continuidade - o que não impediu os conflitos - dada à capacidade do catolicismo de incorporar traços de outras crenças, na relação entre protestantes e adeptos da pajelança verifica-se um processo oposto, visto que há uma demonização e tentativa de expurgo do universo de crenças da pajelança, o que não deixa de ser um processo de incorporação da religião do outro, no entanto, com sentido negativo. Isso se deve ao caráter de intolerância do protestantismo em relação a outras crenças, sejam cristãs ou não.

Chamamos atenção para a possibilidade de mudanças de comportamentos acerca da prática da pajelança no ambiente marajoara, tendo em vista o contexto de conversão ao pentecostalismo, assim como a possibilidade de adaptação do pentecostalismo a algumas crenças locais. Pensamos que seja apressado falar em refluxo de práticas da pajelança tendo em vista a conversão ao pentecostalismo, até porque grande parte dos dirigentes e pastores responsáveis pelas denominações são nativos da região e de alguma forma compartilham do universo de crenças comuns a todos, além de que nos menores povoados esses pastores não possuem formação em seminários teológicos.

8 Por ocasião da pesquisa na região do Salgado, Maués (1995) também verificou que o termo pajelança nunca é usado pelas populaçôes nativas, sendo, portanto, uma categoria de análise criada pelo pesquisador. No Marajó, de forma geral, o termo também não é utilizado pelas populaçóes ribeirinhas. Tal qual o termo pajé, o termo pajelança assume caráter pejorativo, sendo, portanto, mais uma acusação e menos uma designação chamar alguém de pajé. No entanto, já se percebe alguma movimentação nessa questão, e a pajé Zeneida Lima, marajoara, se designa como pajé e divulga a sua prática para o Brasil e para fora do país através dos livros e artigos que escreve e da ONG O Mundo Místico dos Caruanas, que coordena no município de Soure.

Debates do NER, Porto Alegre, ANo I4, N. 24, P. 245-27I, JUl./DEZ. 2013 
Esse processo pelo qual passam as cidades marajoaras pode ser traduzido por aquilo que Hervieu-Lèger (2005), seguindo Lévi-Strauss, chamou de bricolage, que no campo religioso significa a capacidade que o indivíduo tem de "recompor" suas próprias crenças, estando essa recomposição fora de qualquer referência a um corpo institucional válido, devido justamente à anterior desarticulação entre crenças e práticas que, por sua vez, só é possível dada à incapacidade da instituição religiosa de regular totalmente a vida do indivíduo.

As presenças pentecostal e neopentecostal, mesmo esta última sendo muito tímida, têm redimensionado o olhar da Igreja Católica acerca de suas práticas. Em alguns lugares, celebrações antes consideradas "folclóricas", que a igreja lutou longamente no sentido de excluí-las ou transformá-las totalmente, atualmente são aceitas e até incentivadas pela Igreja. Em outros, a luta pela disciplina e pureza ritual permanece. Em ambos os casos, o que se deseja é a manutenção da Igreja Católica e do catolicismo como instituição religiosa dominante. É possível que tal fenômeno possa conduzir a uma "nova" forma de relação entre catolicismo popular e catolicismo eclesial, mas essa nova (?) forma não se caracteriza como ruptura, já que carrega consigo o desejo de controle de que fala Maués (1995), da forma eclesial sobre a forma popular. A Instituição alerta que:

Se a Igreja não reinterpretar a religião do povo latino-americano, se dará um vazio que será ocupado pelas seitas, pelos messianismos políticos secularizados, pelo consumismo que produz tédio e a indiferença ou o pansexualismo pagão. Novamente a Igreja enfrenta o problema: o que não é assumido em Cristo, não é redimido e se constitui em ídolo novo com malícia antiga (Conferência de Puebla, CELAM, 2004, p. 407-408).

Especialmente no caso do Marajó, novos arranjos se configuram. Tendo em vista a relação entre católicos e pentecostais, de fato esses arranjos não caminham para um contexto ecumênico, visto que nenhuma igreja pentecostal faz parte do CONIC - Conselho Nacional de Igrejas Cristãs do Brasil, o que caracterizaria uma relação formal de ecumenismo. As relações "amistosas" ficam por conta das disposições particulares de padres e pastores, que se comportam de acordo com suas inclinações pessoais.

Debates do NER, Porto Alegre, ANo I4, N. 24, P. 245-27I, JUl./DeZ. 2013 
O atual contexto nos leva a afirmar que não se pode pensar na região investigada apenas como espaço católico onde coexistem práticas da pajelança e de religióes de matriz afro que, dado ao caráter inclusivo do catolicismo, foram ao longo do tempo envolvidas por este e adquiriram uma identidade católica, mesmo se constituindo em algo diferente na prática. Com a chegada do pentecostalismo na região, no inicio do século XX, e sua expansão nas duas últimas décadas do mesmo século, esse cenário tende a se alterar. Tal alteração se deve ao fato de que nesse universo religioso se opera um processo diferente daquele verificado com as outras formas religiosas ou de cultos que por longo tempo estiveram sob o manto do catolicismo. Para os pentecostais há uma marcação identitária bastante acentuada e seus adeptos fazem questão de se diferenciar dos católicos, assim como dos praticantes da umbanda, do candomblé, do kardecismo, entre outros. Dessa forma, tem-se um grupo religioso que forja uma identidade que se constrói na/pela diferenciação religiosa.

Mas nem tudo são diferenças, e há bastante continuidade nesse processo. Entender os pentecostais na região marajó pressupõe pensá-los em seu contexto espaço-temporal, sem deixar de considerar todas as questôes que envolvem uma sociedade historicamente construída numa íntima relação com a natureza, a qual tem um peso marcante no cotidiano dessas comunidades, sobretudo no repertório das crenças. Assim, o pentecostalismo que se fixou nessa parte da Amazônia Brasileira dialoga com as características locais relativas às crenças que por longo tempo fizeram/fazem parte do imaginário dessas populações que, sendo convertidas ou nascidas no universo evangélico, não deixam de trazer consigo práticas e crenças de seu antigo repertório cultural-religioso, no caso dos convertidos, ou mesmo de cultivar tal repertório, no caso daqueles que nasceram em "berço evangélico". Esse repertório está quase sempre relacionado às crenças em entidades sobrenaturais como o boto, a matintapereras e os bichos visagentos, entre outros, ou às práticas cristãs católicas, como a benzeção, associada ao uso de uma medicina tradicional que manipula medicamentos feitos à base de ervas naturais.

Das denominações pentecostais, a Assembleia de Deus é a que tem maior apelo entre as populações locais. Outras denominações já tentaram por várias vezes na última década abrir templos na região e não conseguiram

Debates do NER, Porto Alegre, ANo I4, N. 24, P. 245-27I, JUl./DeZ. 2013 
se fixar por falta de fiéis, e um exemplo marcante disso é a Igreja Universal do Reino de Deus. Nos municípios em que possui templos, sua presença já constitui segunda ou terceira tentativa, e ainda assim é pouco expressiva. Outra igreja que tenta se implantar com certo insucesso é a Igreja Mundial do Poder de Deus. Presente no município de Portel, a denominação tem desejo de abrir templos nas cidades de Melgaço e Breves, mas "[...] não está sendo fácil”, comenta seu dirigente.

O gosto dos marajoaras é pelas denominações consideradas "tradicionais" como a Assembleia de Deus, a Deus é Amor, a Igreja do Evangelho Quadrangular, a Igreja Cristã Evangélica, entre outras, e há desconfiança dos mesmos em relação às características dessas novas igrejas. Apesar de reconhecer que Deus é um só, mas pode se manifestar em todas as religiões, o que faz com que haja certa tolerância religiosa entre as várias denominações, os marajoaras entendem que o evangélico é uma pessoa diferente das outras, e é seu dever ser diferente. Suas vestes, seu cabelo, seu comportamento, enfim, sua conduta deve ser exemplar. Não apenas os membros de uma denominação devem cultivar um comportamento condizente, mas, sobretudo, o pastor ou dirigente deve ser uma pessoa que inspire o respeito e a admiração de todos.

Tendo em vista esse zelo com a conduta, as denominações que não exigem um rigor na aparência e que não pregam uma clara distinção entre o universo evangélico e as "coisas do mundo" atraem pouca atenção das famílias marajoaras. Geralmente, essas igrejas mais "modernas" recrutam seus membros naquelas camadas médias de jovens trabalhadores que querem ser evangélicos, porém não desejam abrir mão de antigas práticas como vestir "roupas da moda", jogar futebol, frequentar as praias com trajes de banho, entre outras. Essas igrejas são caracterizadas por celebrarem reuniōes bastante animadas que, segundo os evangélicos mais antigos, "nem parece culto", e há também uma grande flexibilidade relacionada aos costumes, fato também visto com muita desconfiança pelos mais tradicionais. Esse é o caso da denominação Comunidade Evangélica Integrada da Amazônia - CEIA. Presente no município de Portel, ela é frequentada por jovens universitários e trabalhadores liberais, suas reuniōes são bastante animadas, e as pessoas que a frequentam não poderiam ser identificadas como evangélicas apenas por sua aparência,

Debates do NER, Porto Alegre, ANo I4, N. 24, P. 245-27I, JUl./DeZ. 2013 
como no passado. É o caso também da Igreja Universal do Reino de Deus que, mesmo tendo como alvo aquelas pessoas que passam por graves problemas sociais, sobretudo os envolvidos com drogas, furtos, roubos e demais mazelas, problemas enfrentados pela maioria das comunidades, tem uma presença bastante tímida e, pode-se dizer, goza de pouco prestígio na região.

No Marajó, como nos demais lugares, pertencer a uma denominação pentecostal não é uma questão religiosa apenas, e constitui um lugar de hierarquias sociais que varia de acordo com o prestígio da denominação em questão, assim como daqueles que a frequentam. Portanto, dizer que se pertence a esta ou àquela denominação revela um pouco da classe social a que se pertence ou para a qual se almeja transitar, assim como os gostos referentes a essa classe. Quanto mais tradição a denominação tiver, mais prestígio ela agrega a seu membro. E o contrário também procede.

É nesse sentido que a Assembleia de Deus se destaca na região e goza de bastante prestígio. Não apenas por ser a denominação pioneira do pentecostalismo na região, mas, sobretudo, por sustentar a identidade de uma denominação "tradicional" que não sucumbe aos apelos do neopentecostalismo em sua luta por "prosperidade" aqui e agora, e por manter muito zelo e discrição no modelo dos cultos e um rígido padrão de comportamento para com seus adeptos, sobretudo com as mulheres, além de um ethos que despreza as coisas do "mundo" e preza pela salvação da alma.

\section{CONSIDERAÇÕES FINAIS}

As distinções culturais existentes entre as igrejas da Assembleia de Deus da cidade de Imperatriz/MA e das ilhas do arquipélago do Marajó, no Estado do Pará, são produzidas pelas condições econômicas de cada região. Apesar de rural, sofrendo forte influência da cultura indígena, as transformações nas AD's da região do Marajó não estão ocorrendo em maior velocidade em função das idiossincrasias locais, mas sim do isolamento regional e de uma economia frágil e incapaz de atrair levas de imigrantes e de investimentos econômicos significativos. Esse fato reflete no campo religioso, uma vez que igrejas do ramo neopentecostal não conseguem se

Debates do NER, Porto Alegre, ANo I4, N. 24, P. 245-27I, JUl./DEZ. 2013 
estabelecer, e mesmo quando se instalam, não crescem o suficiente para modificar e acirrar a concorrência no mercado religiosa local, polarizada entre as igrejas do pentecostalismo clássico e a Igreja Católica. As AD’s na região do Marajó encontram-se em "zonas de conforto", não tendo necessidades, por enquanto, de promoverem mudanças na sua estrutura eclesiológica.

As AD's na cidade de Imperatriz/MA vivem uma situação totalmente diferente. Localizadas em região de grande crescimento econômico e populacional, sofrem concorrência das igrejas neopentecostais e ainda precisam se ajustar aos novos valores preconizados pela sociedade de consumo (Bauman, 2008), modicando seu ethos e alterando suas práticas e crenças na busca da manutenção de sua posição e de seu crescimento no campo religioso local.

\section{REFERÊNCIAS}

AGOSTINI, Nilo. Ética e Evangelização. Petrópolis: Vozes, 1992.

BAUMAN, Zygmunt. Vida para consumo. Tradução de Carlos Alberto Medeiros. Rio de Janeiro: Zahar, 2008.

BÍBLIA. Bíblia Sagrada. São Paulo: Sociedade Torre de Vigia de Bíblias e Tratados, 1986.

CAMPOS, Leonildo. Teatro, Templo e Mercado: Organização e Marketing de um empreendimento Pentecostal. Petrópolis: Vozes, 1999.

CONSELHO EPISCOPAL LATINO-AMERICANO. Documentos do CELAM: conclusóes das Conferências do Rio de Janeiro, de Medellín, Puebla e Santo Domingo. São Paulo: Paulus, 2004.

COSTA, Moab César Carvalho. Mudanças de ethos do pentecostalismo clássico para o neopentecostal. Estudo de Caso: a Assembleia de Deus em Imperatriz-MA. 2011. p. 160. Dissertação (Mestrado em Ciências da Religião) - Pontifícia Universidade Católica de Goiás, Goiânia, 2011.

Debates do NER, Porto Alegre, ANo I4, N. 24, P. 245-27I, JUl./DeZ. 2013 
FRESTON, Paul. Protestantes e politica no Brasil: da constituição ao impeachment. Tese (Doutorado em Sociologia) - Instituto de Filosofia e Ciências Humanas, Universidade Estadual de Campinas, Campinas, 1993.

GEERTZ, Clifford. A interpretação das culturas. Rio de Janeiro: Guanabara, 2008.

GUERRA, Lemuel. Mercado Religioso no Brasil: Competição, demanda e a dinâmica da esfera da religião. João Pessoa: Ideia, 2003.

HERVIEU-LÈGER, Danièle. O peregrino e o convertido: a religião em movimento. Portugal: Gradiva, 2005.

INSTITUTO BRASILEIRO DE GEOGRAFIA E ESTATÍSTICA. Recenseamento Geral do Brasil - 1940: Estado do Maranhão. Censo demográfico: População e Habitação. Censos Econômicos: agrícola, industrial, comercial e de serviços. Série Regional, parte IV. IBGE: Rio de Janeiro, 1940.

. VI Recenseamento Geral do Brasil-1950. Estado do Maranhão: Censo Demográfico. Série Regional: v. XII, tomo I. IBGE: Rio de Janeiro, 1955.

Censo Demográfico de 1960: Maranhão - Piauí. VII Recenseamento Geral do Brasil. Série Regional: v. I, tomo III. IBGE: Rio de Janeiro, 1968. Censo Demográfico: Maranhão. VIII Recenseamento Geral - 1970. Série Regional: v. I, tomo V. IBGE: Rio de Janeiro, 1973.

IX Recenseamento Geral do Brasil-1980. Censo Demográfico: dados gerais, migração, instrução, fecundidade e mortalidade - Maranhão. v. I, tomo IV, n. 7. IBGE: Rio de Janeiro, 1982.

Censo Demográfico - 1991: Características Gerais da População e Instrução. n. 9, Maranhão. IBGE: Rio de Janeiro, 1991.

. Censo Demográfico 2000: características gerais da população. IBGE: Rio de Janeiro, 2003. CD-ROM.

ISTOÉ Independente, n. 2167, 20 maio 2011. 
MARIANO, Ricardo. Neopentecostalismo: sociologia do novo pentecostalismo no Brasil. São Paulo: Loyola, 2005.

MAUÉS, Raymundo Heraldo. Padres, pajés, santos e festas: catolicismo popular e controle eclesiástico. Belém: Cejup, 1995.

MONTES, Maria Lucia. As figuras do sagrado: entre o público e o privado. In: SCHWARCZ, Lilia Moritz (Org.). História da vida privada no Brasil. v. 4: Contrastes da intimidade contemporânea. São Paulo: Cia das Letras, 1998. p. 63-171.

PANTOJA, Vanda. Santos e Espirito Santo, ou Católicos e Evangélicos na Amazônia Marajoara. Tese (Doutorado em Antropologia Social) - Universidade Federal do Pará, Belém, 2011.

ROMEIRO, Paulo. Decepcionados com a Graça: esperanças e frustraçōes no Brasil neopentecostal. São Paulo: Mundo Cristão, 2005.

SANCHIS, Pierre. O campo religioso no Brasil. In: ORO, Ari; STEIL, Carlos Alberto (Orgs.). Religião e Globalização. Petrópolis: Vozes, 1997. p. 103-115.

VINGREN, Ivar. Diário do Pioneiro Gunnar Vingren. Rio de Janeiro: CPAD, 2000.

WEBER, Max. Economia e sociedade. Tradução de Regis Barbosa e Karen Elsabe Barbosa; rev. téc. de Gabriel Conh. 4. ed. Brasília: UNB, 2009. v. 1. . A Etica Protestante e o Espirito do Capitalismo. São Paulo: Editora Martin Claret, 2001.

Debates do NER, Porto Alegre, ANo I4, N. 24, P. 245-27I, JUl./DeZ. 2013 